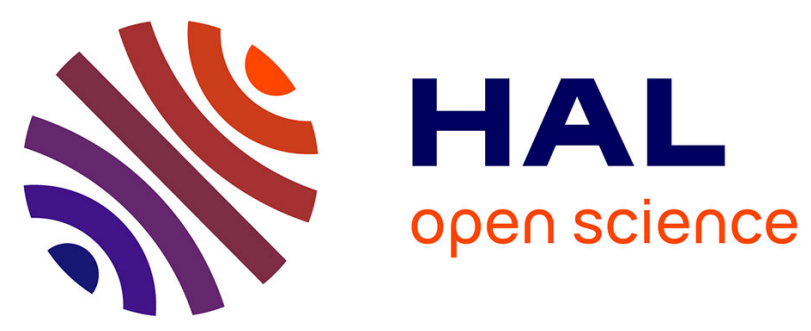

\title{
Influence of the solvent and of the reaction concentration for palladium-catalysed direct arylation of heteroaromatics with 4-bromoacetophenone
}

Souhila Bensaid, Henri Doucet

\section{- To cite this version:}

Souhila Bensaid, Henri Doucet. Influence of the solvent and of the reaction concentration for palladium-catalysed direct arylation of heteroaromatics with 4-bromoacetophenone. Comptes Rendus. Chimie, 2014, 17 (12), pp.1184-1189. 10.1016/j.crci.2014.02.004 . hal-01114992

HAL Id: hal-01114992

https://hal-univ-rennes1.archives-ouvertes.fr/hal-01114992

Submitted on 4 Feb 2016

HAL is a multi-disciplinary open access archive for the deposit and dissemination of scientific research documents, whether they are published or not. The documents may come from teaching and research institutions in France or abroad, or from public or private research centers.
L'archive ouverte pluridisciplinaire HAL, est destinée au dépôt et à la diffusion de documents scientifiques de niveau recherche, publiés ou non, émanant des établissements d'enseignement et de recherche français ou étrangers, des laboratoires publics ou privés. 

sée au palladium d'hétéroaromatiques par la 4 bromoacétophénone

\title{
Influence of the solvent and of the reaction concentration for palladium- catalysed direct arylation of heteroaromatics with 4-bromoacetophenone
}

\author{
Souhila Bensaid, ${ }^{[\mathrm{a}]}$ Henri Doucet ${ }^{\star[a]}$ \\ [a] Institut Sciences Chimiques de Rennes, UMR 6226 CNRS-Université de Rennes 1 \\ "Catalyse et Organometalliques", Campus de Beaulieu, 35042 Rennes, France. \\ Tel: +(33) 0223236384; Fax: +(33) 0223236939. \\ E-mail: henri.doucet@univ-rennes1.fr
}

\begin{abstract}
Solvent is certainly one of the main source of wastes during palladium-catalysed direct arylation reactions. We found that such direct arylations of heteroaromatics can be performed using very high reaction concentrations $(0.5 \mathrm{M}-5 \mathrm{M})$. However, the Pd-catalyst precursor used must be adapted to both the solvent nature and reaction concentration. The reactions performed in DMA, NMP or DMF can be carried out in very concentrated reaction mixtures using $0.1 \mathrm{~mol} \% \mathrm{Pd}(\mathrm{OAc})_{2}$ catalyst without phosphine ligand. On the other hand, the reactions in CPME, pentan-1-ol or diethylcarbonate should be performed with a palladium catalyst associated to a phosphine ligand. These reaction conditions allow to reduce the amount of wastes formed in the course of these couplings.
\end{abstract}

Résumé: Le solvant est certainement l'une des principales sources de déchets lors des réactions d'arylation directes d'hétéroaromatiques catalysées au palladium. Nous avons constaté que ces réactions peuvent être réalisées en utilisant des concentrations très élevées $(0,5 \mathrm{M}-5 \mathrm{M})$. Cependant, le catalyseur de palladium utilisé doit être adapté à la fois à la nature du solvant et à la concentration de la réaction. Les réactions effectuées dans le DMA, la NMP ou le DMF peut être réalisée dans des mélanges réactionnels très concentrés en utilisant $0,1 \mathrm{~mol} \%$ de $\mathrm{Pd}(\mathrm{OAc})_{2}$ sans addition le ligand de type phosphine. Par contre, les réactions dans le CPME, le pentan-1-ol ou le carbonate de diéthyle doivent être effectuée avec un catalyseur de palladium associé à un ligand phosphine. Ces conditions de réaction permettent de réduire la quantité de déchets formés au cours de ces couplages.

Keywords: aryl bromides, catalysis, C-H activation, heteroaromatics, palladium, concentration.

Mots clés: bromures d'aryle, catalyse, activation $\mathrm{C}-\mathrm{H}$, hétéroaromatiques, palladium, concentration.

Introduction

The synthesis of arylated heteroaromatics is an important field for research in organic synthesis due to the physical or biological properties of these compounds. In 1990, Ohta et al. reported that the direct arylation of several heteroaromatics with aryl halides proceed in moderate to good yields using $\mathrm{Pd}\left(\mathrm{PPh}_{3}\right)_{4}$ as the catalyst and DMA (N,N-dimethylacetamide) as the solvent. ${ }^{[1]}$ Since these very innovative results, the Pd-catalysed direct arylation of heteroaromatics with aryl halides or pseudo-halides has been demonstrated to be an extremely powerful method for the synthesis of a variety of arylated heterocycles in a few steps. ${ }^{[2]}$ This reaction provides a cost-effective access to such compounds. Moreover, the major wastes of the reaction are a base associated to $\mathrm{HX}$ and the reaction solvent, instead of metallic salts produced under classical cross-coupling procedures such as Suzuki, Negishi or Stille reactions. ${ }^{[3]}$ The method avoids the preliminary preparation of an organometallic reducing the number of steps to prepare these compounds. However, these coupling reactions are generally performed using large amounts of relatively toxic solvents such as DMA, DMF, NMP or dioxane. ${ }^{[4-6]}$ In recent years, a few solvents which can be considered as "greener"[7] according to $P$. Anastas principles, have been employed for direct arylations. ${ }^{[8]}$ For example, Greaney and Djakovitch reported that, using water as solvent, the direct arylation of oxazoles, thiazoles, indazoles or indoles proceeds nicely. ${ }^{[9]}$ René and Fagnou employed a mixture of water and EtOAc for the direct arylation of thiophenes. ${ }^{[10 a]}$ Polyethylene glycol (PEG 20000) has been found to promote the direct arylation of triazoles. ${ }^{[10 \mathrm{~b}]}$ Carbonates, ethers or alcohols have also been suc- 
cessfully employed for the direct arylation of some heteroaromatics. ${ }^{[1]}$ The ruthenium-catalysed direct arylation of 2-arylpyridines in carbonates or water has been reported by Fischmeister, Dixneuf and co-workers. ${ }^{[12]}$

Waste prevention is a major requirement in current organic synthesis. One of the most promising approaches to reduce the formation of wastes is solvent-free or highly concentrated reactions. ${ }^{[13,14]}$ Such conditions make syntheses easier due to the reduction in reactor size and to simpler work-up as there is less solvent to eliminate at the end of the reaction. Therefore, the use of such conditions for Pd-catalysed direct arylations would be environmentally attractive for the preparation of arylated heteroarenes.

To our knowledge, the influence of the reaction concentration using various solvents for the palladium-catalysed direct arylation of heteroaromatics has not yet been studied. Herein, we wish to report on the palladiumcatalysed direct arylations of a range of heteroaromatic derivatives with an aryl bromide using a set of solvents under various reaction concentrations.

\section{Results and discussion}

For this study, six solvents were employed. DMA and DMF which are classified as "undesirable" solvents for industrial application; NMP which is "usable", and also pentan-1-ol, cyclopentylmethylether (CPME) and diethylcarbonate which are among the "preferred" solvents. ${ }^{[15]}$

The use of CPME as solvent presents several advantageous features such as a high hydrophobicity. Its limited miscibility in water allows an easy separation and recovery from water. Other preferable characteristic is the low formation of peroxides compared to THF or diisopropyl ether. Moreover, CPME can be manufactured by the addition of $\mathrm{MeOH}$ to cyclopentene, which produces no apparent waste. ${ }^{[16]}$ Pentan-1-ol is not considered a hazardous air pollutant solvent, is readily biodegradable and practically non-toxic to fish and aquatic organisms. Pentan-1-ol can be prepared by the reduction of 1-valeraldehyde with hydrogen or by fermentation and is present in cider, beer or wine to varying degrees. Therefore, exposure to residual amounts of this alcohol is unlikely to have any adverse health effects. Diethylcarbonate is a polar, aprotic, nontoxic, and biodegradable solvent. ${ }^{[17]}$ Based on these properties, it also offers an environmentally friendly alternative to standard polar solvents. Therefore, the use of CPME, pentan-1-ol or diethylcarbonate as solvents is in agreement with the principles 1, 5 and 12 of "green chemistry"[7]

We have recently reported that phosphine-free $\mathrm{Pd}(\mathrm{OAc})_{2}$ catalyst promotes very efficiently the direct arylation of some heteroaromatics in DMA. ${ }^{[8]}$ We initially employed this phosphine-free procedure in order to determine the influence of the amount and nature of the solvent for Pd-catalysed direct arylations. A first set of reactions using thiophene 2-carbonitrile $(0.75 \mathrm{mmol})$ and 4-bromoacetophenone $(0.5 \mathrm{mmol})$ as the coupling partners was carried out under previously reported reaction conditions, ${ }^{[18]}$ but in 4,1 or $0.5 \mathrm{~mL}$ of solvent with only $0.1 \mathrm{~mol} \%$ $\mathrm{Pd}(\mathrm{OAc})_{2}$ catalyst (Table 1 , column 3 ). In the presence of polar solvents, DMA, NMP and DMF, high conversions of 4-bromoacetophenone and yields of coupling product 1 were obtained (Table 1, entries 1-3, 5-7 and 911 in column 3). The use of $0.1 \mathrm{~mL}$ of these three solvents (concentration $5 \mathrm{M}$ ) and again $0.1 \mathrm{~mol} \% \mathrm{Pd}(\mathrm{OAc})_{2}$ catalyst led to lower conversion of 4-bromoacetophenone of 36, 30 and 66\% (Table 1, entries 4, 8 and 12 in column 3). Then, we employed 0.1-4 mL of pentan-1-ol, diethylcarbonate or CPME as the solvent and again $0.1 \mathrm{~mol} \% \mathrm{Pd}(\mathrm{OAc})_{2}$ catalyst. In all cases, poor conversions of 4-bromoacetophenone were obtained (Table 1, entries 13-24 in column 3). The use of a higher catalyst loading of $0.5 \mathrm{~mol} \% \mathrm{of} \operatorname{Pd}(\mathrm{OAc})_{2}$ catalyst was found to increase the conversion of 4-bromoacetophenone for the reactions performed in $0.1 \mathrm{~mL}$ of DMA or NMP (Table 1 , entries 4 and 8 in column 4); whereas, it was not profitable for reaction performed in pentan-1-ol and less profitable for reaction performed diethylcarbonate (Table 1, entries 14-16, 19 and 20 in column 4). With this ligand-free catalyst, under higher palladium concentrations, so-called "palladium black" forms more rapidly when pentan-1-ol or diethylcarbonate are used as the solvents. Therefore, the concentration of active palladium species is not increased, and the conversions of 4-bromoacetophenone were not improved. This ligand-free procedure has to be employed only with solvents which display coordination properties with palladium. Therefore, in order to obtain higher yields with pentan-1-ol, diethylcarbonate or CPME solvents, we employed 0.1 or $0.5 \mathrm{~mol} \%$ $\mathrm{PdCl}\left(\mathrm{C}_{3} \mathrm{H}_{5}\right)(\mathrm{dppb})$ as the catalyst. In pentan-1-ol, much better results were obtained even in the presence of only $0.1 \mathrm{~mL}$ of solvent (concentration $5 \mathrm{M}$ ) (Table 1, entries 14-16 in columns 5 and 6). For reactions in diethylcarbonate, similar conversions of $60-68 \%$ of 4-bromoacetophenone were obtained using $1,0.5$ or $0.1 \mathrm{~mL}$ of solvent and $0.5 \mathrm{~mol} \% \mathrm{PdCl}\left(\mathrm{C}_{3} \mathrm{H}_{5}\right)(\mathrm{dppb})($ Table 1, entries 18-20 in column 6). For the reactions in $\mathrm{CPME}$, the best results were obtained using 1 or $0.5 \mathrm{~mL}$ of solvent (Table 1, entries 22-24 in column 6). In summary, the phosphine-free procedure can be employed with DMA, NMP and DMF as the solvents, whereas using $\mathrm{PdCl}\left(\mathrm{C}_{3} \mathrm{H}_{5}\right)(\mathrm{dppb})$ catalyst [dppb: 1,4-bis(diphenylphosphino)butane] appears to be more reliable for reactions in pentan-1-ol, diethylcarbonate or CPME. For most of these solvents, reaction concentrations of $1 \mathrm{M}$ can be employed. 
Table 1: Influence of the solvent nature and of the concentration on the Pd-catalysed 5-arylation of thiophene 2carbonitrile with 4-bromoacetophenone

\begin{tabular}{|c|c|c|c|c|c|}
\hline Entry & Solvent (mL) & $\begin{array}{c}\mathrm{Pd}(\mathrm{OAc})_{2} \\
(0.1 \mathrm{~mol} \%) \\
\text { Conv. (\%) }\end{array}$ & $\begin{array}{l}\mathrm{Pd}(\mathrm{OAc})_{2} \\
(0.5 \text { mol\%) } \\
\text { Conv. (\%) }\end{array}$ & $\begin{array}{c}\mathrm{PdCl}\left(\mathrm{C}_{3} \mathrm{H}_{5}\right)(\mathrm{dppb}) \\
(0.1 \mathrm{~mol} \%) \\
\text { Conv. (\%) }\end{array}$ & $\begin{array}{c}\mathrm{PdCl}\left(\mathrm{C}_{3} \mathrm{H}_{5}\right)(\mathrm{dppb} \\
\quad(0.5 \mathrm{~mol}) \\
\text { Conv. }(\%)\end{array}$ \\
\hline 1 & DMA (4) & $100(88)$ & & & \\
\hline 2 & DMA (1) & 100 & & & \\
\hline 3 & DMA (0.5) & $100(85)$ & & & \\
\hline 4 & DMA (0.1) & 36 & 74 & 54 & $100(82)$ \\
\hline 5 & NMP (4) & 73 & & & \\
\hline 6 & NMP (1) & 100 & & & \\
\hline 7 & NMP (0.5) & $100(83)$ & & & \\
\hline 8 & NMP (0.1) & 30 & 63 & & \\
\hline 9 & DMF (4) & 100 & & & \\
\hline 10 & DMF (1) & 100 & & & \\
\hline 11 & DMF (0.5) & $100(80)$ & & & \\
\hline 12 & DMF (0.1) & 66 & 42 & 25 & \\
\hline 13 & Pentan-1-ol (4) & 0 & & & \\
\hline 14 & Pentan-1-ol (1) & 19 & 3 & & \\
\hline 15 & Pentan-1-ol (0.5) & 19 & 8 & 48 & $100(76)$ \\
\hline 16 & Pentan-1-ol (0.1) & 12 & 9 & 39 & 97 \\
\hline 17 & Diethylcarbonate (4) ${ }^{\mathrm{a}}$ & 0 & & & \\
\hline 18 & Diethylcarbonate $(1)^{\mathrm{a}}$ & 0 & & & 62 \\
\hline 19 & Diethylcarbonate $(0.5)^{\mathrm{a}}$ & 3 & 4 & & $68(56)$ \\
\hline 20 & Diethylcarbonate $(0.1)^{\mathrm{a}}$ & 15 & 24 & & 60 \\
\hline 21 & Cyclopentyl methyl ether $(4)^{\mathrm{b}}$ & 0 & & & \\
\hline 22 & Cyclopentyl methyl ether $(1)^{\mathrm{b}}$ & 0 & & 15 & $100(81)$ \\
\hline 23 & Cyclopentyl methyl ether $(0.5)^{\mathrm{b}}$ & 5 & & & 84 \\
\hline 24 & Cyclopentyl methyl ether $(0.1)^{\mathrm{b}}$ & 10 & & & 67 \\
\hline
\end{tabular}

Conditions : 4-bromoacetophenone $(0.5 \mathrm{mmol})$, thiophene 2-carbonitrile $(0.75 \mathrm{mmol}), \mathrm{KOAc}(1 \mathrm{mmol}), 6 \mathrm{~h}, 150{ }^{\circ} \mathrm{C}$, isolated yield in parenthesis. ${ }^{a}$ Reaction temperature $130{ }^{\circ} \mathrm{C}$. ${ }^{\mathrm{b}}$ Reaction temperature $125^{\circ} \mathrm{C}$.

Then, we studied the 5-arylation of a furan derivative with these six solvents at different concentrations (Table 2). In general, furan derivatives are less reactive than thiophenes for Pd-catalysed direct arylations. ${ }^{[11 e]}$ With 1 $\mathrm{mL}$ of DMA, NMP or DMF, $0.5 \mathrm{mmol}$ of 4-bromoacetophenone (concentration $0.5 \mathrm{M})$ and $0.1 \mathrm{~mol} \% \mathrm{Pd}(\mathrm{OAc})_{2}$ catalyst, high or complete conversions of 4-bromoacetophenone were observed (Table 2, entries 1, 4 and 7 , column 3). On the other hand, the use of only $0.1 \mathrm{~mL}$ of solvent for $0.5 \mathrm{mmol}$ of aryl bromide (concentration 5 $\mathrm{M}$ ) led to poor conversions in these three solvents (Table 2, entries 3, 6 and 9, column 3). Again, the reactions performed in pentan-1-ol, diethylcarbonate or CPME using $\mathrm{Pd}(\mathrm{OAc})_{2}$ catalyst led to low conversions of 4bromoacetophenone (Table 2, entries 10-18, columns 3 and 4); whereas, the use of $0.5 \mathrm{~mol} \% \mathrm{PdCl}\left(\mathrm{C}_{3} \mathrm{H}_{5}\right)(\mathrm{dppb})$ catalyst and 0.1 or $0.5 \mathrm{~mL}$ in these solvents led to good yields of 2 (Table 2, entries 11,15 and 18, column 6). It should be noted that, for this reaction, with diethylcarbonate or CPME as the solvents, better results were obtained in more concentrated reaction mixtures $(5 \mathrm{M}$ or $1 \mathrm{M}>0.5 \mathrm{M})$. 
Table 2: Influence of the solvent nature and of the concentration on the Pd-catalysed 5-arylation of ethyl 2methylfuran-3-carboxylate with 4-bromoacetophenone

\begin{tabular}{|c|c|c|c|c|c|}
\hline Entry & Solvent (mL) & $\begin{array}{c}\mathrm{Pd}(\mathrm{OAc})_{2} \\
(0.1 \text { mol\%) } \\
\text { Conv. (\%) }\end{array}$ & $\begin{array}{c}\mathrm{Pd}(\mathrm{OAc})_{2} \\
(0.5 \mathrm{~mol} \%) \\
\text { Conv. (\%) }\end{array}$ & $\begin{array}{c}\mathrm{PdCl}\left(\mathrm{C}_{3} \mathrm{H}_{5}\right)(\mathrm{dppb}) \\
(0.1 \mathrm{~mol} \%) \\
\text { Conv. (\%) }\end{array}$ & $\begin{array}{c}\mathrm{PdCl}\left(\mathrm{C}_{3} \mathrm{H}_{5}\right)(\mathrm{dppb} \\
(0.5 \mathrm{~mol}) \\
\text { Conv. (\%) }\end{array}$ \\
\hline 1 & DMA (1) & 100 & & & \\
\hline 2 & DMA (0.5) & $100(87)$ & & & \\
\hline 3 & DMA $(0.1)$ & 14 & 100 & 42 & $100(82)$ \\
\hline 4 & NMP (1) & 79 & 100 & & \\
\hline 5 & NMP (0.5) & 58 & $100(85)$ & & \\
\hline 6 & NMP (0.1) & 11 & 100 & & \\
\hline 7 & DMF (1) & 100 & & & \\
\hline 8 & DMF (0.5) & 57 & $100(82)$ & & \\
\hline 9 & $\operatorname{DMF}(0.1)$ & 4 & 47 & & $100(80)$ \\
\hline 10 & Pentan-1-ol (1) & 41 & & & \\
\hline 11 & Pentan-1-ol (0.5) & 34 & & & $100(81)$ \\
\hline 12 & Pentan-1-ol (0.1) & 3 & 40 & 26 & \\
\hline 13 & Diethylcarbonate $(1)^{\mathrm{a}}$ & 0 & 0 & 2 & 6 \\
\hline 14 & Diethylcarbonate $(0.5)^{\mathrm{a}}$ & 0 & 2 & 2 & 32 \\
\hline 15 & Diethylcarbonate $(0.1)^{\mathrm{a}}$ & 10 & 2 & 7 & $100(76)$ \\
\hline 16 & Cyclopentyl methyl ether $(1)^{\mathrm{b}}$ & 0 & 0 & 1 & 4 \\
\hline 17 & Cyclopentyl methyl ether $(0.5)^{\mathrm{b}}$ & 0 & 0 & 2 & 23 \\
\hline 18 & Cyclopentyl methyl ether $(0.1)^{\mathrm{b}}$ & 5 & 0 & 5 & $100(84)$ \\
\hline
\end{tabular}

Conditions : 4-bromoacetophenone (0.5 mmol), ethyl 2-methylfuran-3-carboxylate $(0.75 \mathrm{mmol}), \mathrm{KOAc}(1 \mathrm{mmol}), 6 \mathrm{~h}, 150{ }^{\circ} \mathrm{C}$, isolated yield in parenthesis. ${ }^{\mathrm{a}}$ Reaction temperature $130{ }^{\circ} \mathrm{C}$. ${ }^{\mathrm{b}}$ Reaction temperature $125^{\circ} \mathrm{C}$.

Finally, the 2-arylation of 1-methylpyrrole with 4-bromoacetophenone was studied using again various amounts of the six solvents (Table 3). The use $0.1,0.5$ or $1 \mathrm{~mL}$ of DMA, NMP or DMF for reaction of $0.5 \mathrm{mmol}$ of 4 bromoacetophenone in the presence of $0.1 \mathrm{~mol} \% \mathrm{Pd}(\mathrm{OAc})_{2}$ catalyst led to very high or complete conversions of the starting material, in most cases (Table 3, entries 1-8). A moderate conversion of 4-bromoacetophenone was observed in $0.1 \mathrm{~mL}$ of $\mathrm{DMF}$, and $0.5 \mathrm{~mol} \% \mathrm{Pd}(\mathrm{OAc})_{2}$ catalyst had to been employed to obtain a high conversion of the aryl bromide (Table 3, entry 9). As expected, the use of 0.1 or $0.5 \mathrm{~mol} \%$ of phosphine-free $\mathrm{Pd}(\mathrm{OAc})_{2}$ catalyst in CPME, pentan-1-ol or diethylcarbonate was ineffective; whereas, high or complete conversions were obtained in $0.1 \mathrm{~mL}$ of pentan-1-ol or diethylcarbonate in the presence of $0.5 \mathrm{~mol} \% \mathrm{PdCl}\left(\mathrm{C}_{3} \mathrm{H}_{5}\right)(\mathrm{dppb})$ catalyst (Table 3, entries 10-18). 
Table 3: Influence of the solvent nature and of the concentration on the Pd-catalysed 2-arylation of 1-methylpyrrole with 4-bromoacetophenone

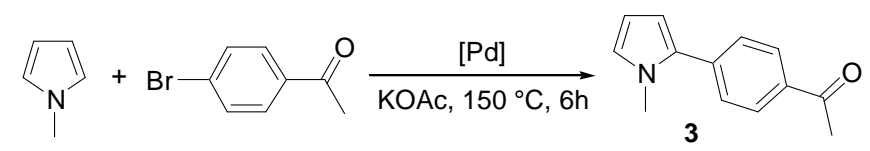

\begin{tabular}{|c|c|c|c|c|}
\hline Entry & Solvent $(\mathrm{mL})$ & $\begin{array}{c}\mathrm{Pd}(\mathrm{OAc})_{2} \\
(0.1 \mathrm{~mol} \%) \\
\text { Conv. }(\%) \\
\end{array}$ & $\begin{array}{c}\mathrm{Pd}(\mathrm{OAc})_{2} \\
(0.5 \text { mol\%) } \\
\text { Conv. (\%) }\end{array}$ & $\begin{array}{c}\mathrm{PdCl}\left(\mathrm{C}_{3} \mathrm{H}_{5}\right)(\mathrm{dppb}) \\
(0.5 \mathrm{~mol} \%) \\
\text { Conv. (\%) } \\
\end{array}$ \\
\hline 1 & DMA (1) & 100 & & \\
\hline 2 & DMA $(0.5)$ & $100(78)$ & & \\
\hline 3 & DMA $(0.1)$ & 97 & & \\
\hline 4 & NMP (1) & 100 & & \\
\hline 5 & NMP (0.5) & $100(75)$ & & \\
\hline 6 & NMP $(0.1)$ & 100 & & \\
\hline 7 & DMF (1) & 100 & & \\
\hline 8 & DMF (0.5) & $100(76)$ & & \\
\hline 9 & DMF (0.1) & 48 & 89 & \\
\hline 10 & Pentan-1-ol (1) & 24 & 34 & \\
\hline 11 & Pentan-1-ol (0.5) & 15 & 21 & \\
\hline 12 & Pentan-1-ol (0.1) & 4 & 4 & $88(61)$ \\
\hline 13 & Diethylcarbonate $(1)^{\mathrm{a}}$ & 4 & 3 & \\
\hline 14 & Diethylcarbonate $(0.5)^{\mathrm{a}}$ & 3 & 3 & 28 \\
\hline 15 & Diethylcarbonate $(0.1)^{\mathrm{a}}$ & 6 & 5 & $100(66)$ \\
\hline 16 & Cyclopentyl methyl ether $(1)^{\mathrm{b}}$ & 2 & 0 & \\
\hline 17 & Cyclopentyl methyl ether $(0.5)^{\mathrm{b}}$ & 1 & 3 & \\
\hline 18 & Cyclopentyl methyl ether $(0.1)^{\mathrm{b}}$ & 3 & 4 & \\
\hline
\end{tabular}

Conditions : 4-bromoacetophenone (0.5 mmol), 1-methylpyrrole (1.5 mmol), KOAc (1 mmol), $6 \mathrm{~h}, 150{ }^{\circ} \mathrm{C}$, isolated yield in parenthesis.

${ }^{\mathrm{a}}$ Reaction temperature $130{ }^{\circ} \mathrm{C}$. ${ }^{\mathrm{b}}$ Reaction temperature $125^{\circ} \mathrm{C}$.

\section{Conclusion}

In summary, these results demonstrate that, the direct arylation of heteroaromatics can be performed with highly concentrated reaction mixtures (up to $5 \mathrm{M}$ ). However, the nature and loading of the catalyst has to be tuned according to the solvent. For reactions in DMA, NMP or DMF, a low loading (0.1-0.5 mol\%) of a phosphine-free catalyst promotes the coupling in high yields. On the other hand, palladium catalyst associated to a phosphine ligand should be preferred for the reactions performed in CPME, pentan-1-ol or diethylcarbonate. These results demonstrate that most of these couplings proceed nicely using highly concentrated reaction mixtures, even in some solvents which are considered as "green". Such reactions conditions allow industrially viable processes, as they reduce the hazards and toxicity associated with the use of solvents, reduce wastes costs, and simplify separation procedure at the end of the reaction.

\section{Experimental section}

$\mathrm{Pd}(\mathrm{OAc})_{2},\left[\mathrm{Pd}\left(\mathrm{C}_{3} \mathrm{H}_{5}\right) \mathrm{Cl}\right]_{2}$, dppb, heteroarenes, 4-bromoacetophenone, KOAc (99\%) were purchased from Alfa Aesar and were not purified before use. DMA (99+\%), NMP (99+\%), DMF (99+\%), pentan-1-ol (99\%), 
cyclopentyl methyl ether (99+\%) and diethylcarbonate (99\%) were purchased from Acros Organics and were not purified before use.

Preparation of the $\mathrm{PdCl}\left(\mathrm{C}_{3} \mathrm{H}_{5}\right)(\mathrm{dppb})$ catalyst: ${ }^{[19]}$ An oven-dried $40 \mathrm{~mL}$ Schlenk tube equipped with a magnetic stirring bar under argon atmosphere, was charged with $\left[\mathrm{Pd}\left(\mathrm{C}_{3} \mathrm{H}_{5}\right) \mathrm{Cl}\right]_{2}(182 \mathrm{mg}, 0.5 \mathrm{mmol})$ and dppb $(426$ $\mathrm{mg}, 1 \mathrm{mmol}$ ). $10 \mathrm{~mL}$ of anhydrous dichloromethane were added, then, the solution was stirred at room temperature for twenty minutes. The solvent was removed in vacuum. The yellow powder was used without purification. ${ }^{31} \mathrm{P}$ NMR $\left(81 \mathrm{MHz}, \mathrm{CDCl}_{3}\right) \delta=19.3$ (s).

\section{Representative procedure for coupling reactions:}

The reaction of 4-bromoacetophenone $(0.100 \mathrm{~g}, 0.5 \mathrm{mmol})$, heteroaromatic $(0.75 \mathrm{mmol})$ and KOAc $(0.098 \mathrm{~g}, 1$ $\mathrm{mmol}$ ) at $125-150^{\circ} \mathrm{C}$ (see tables) in the presence of $\mathrm{PdCl}\left(\mathrm{C}_{3} \mathrm{H}_{5}\right)(\mathrm{dppb})$ or $\mathrm{Pd}(\mathrm{OAc})_{2}$ (see tables) in the appropriate solvent under argon affords the coupling product after filtration on silica gel (pentane/ether).

5-(4-Acetylphenyl)thiophene-2-carbonitrile (1) ${ }^{[20 a]}$

According to representative procedure with 4-bromoacetophenone $(0.100 \mathrm{~g}, 0.5 \mathrm{mmol})$ and thiophene 2carbonitrile $(0.082 \mathrm{~g}, 0.75 \mathrm{mmol})$ in $1 \mathrm{~mL}$ of cyclopentyl methyl ether affords 1 in $81 \%$ yield.

\section{5-(4-Acetylphenyl)-2-methylfuran-3-carboxylic acid ethyl ester (2) ${ }^{[20 b]}$}

According to representative procedure 4-bromoacetophenone $(0.100 \mathrm{~g}, 0.5 \mathrm{mmol})$ and ethyl 2-methylfuran-3carboxylate $(0.116 \mathrm{~g}, 0.75 \mathrm{mmol})$ in $0.1 \mathrm{~mL}$ of diethylcarbonate affords 2 in $76 \%$ yield.

\section{1-[4-(1-Methyl-1H-pyrrol-2-yl)-phenyl]-ethanone (3) ${ }^{[20 c]}$}

According to representative procedure 4-bromoacetophenone $(0.100 \mathrm{~g}, 0.5 \mathrm{mmol})$ and 1-methylpyrrole $(0.122 \mathrm{~g}$, $1.5 \mathrm{mmol}$ ) in $0.1 \mathrm{~mL}$ of diethylcarbonate affords 3 in $66 \%$ yield.

\section{Acknowledgements}

We thank the CNRS and "Rennes Metropole" for providing financial support.

\section{References}

[1] A. Ohta, Y. Akita, T. Ohkuwa, M. Chiba, R. Fukunaga, A. Miyafuji, T. Nakata, N. Tani, Y. Aoyagi, Heterocycles 1990, 31, 1951.

[2] a) D. Alberico, M. E. Scott, M. Lautens, Chem. Rev. 2007, 107, 174; b) T. Satoh, M. Miura, Chem. Lett. 2007, 36, 200; c) L.-C. Campeau, D. R. Stuart, K. Fagnou, Aldrichimica Acta 2007, 40, 35; d) I. V. Seregin, V. Gevoryan, Chem. Soc. Rev. 2007, 36, 1173; e) B.-J. Li, S.-D. Yang, Z.-J. Shi, Synlett 2008, 949; f) F. Bellina, R. Rossi, Tetrahedron 2009, 65, 10269; g) L. Ackermann, R. Vincente, A. R. Kapdi, Angew. Chem. Int. Ed. 2009, 48, 9792; h) X. Chen, K. M. Engle, D.-H. Wang, J.-Q. Yu, Angew. Chem. Int. Ed. 2009, 48, 5094; i) J. Roger, A. L. Gottumukkala, H. Doucet, ChemCatChem 2010, 2, 20; j) D. Lapointe, K. Fagnou, Chem. Lett. 2010, 39, 1119; k) L. Ackermann, Chem. Rev. 2011, 111, 1315.; I) N. Kuhl, M. N. Hopkinson, J. Wencel-Delord, F. Glorius, Angew. Chem. Int. Ed. 2012, 51, 10236; m) J. Wencel-Delord, F. Glorius, Nature Chem. 2013, 5, 369; n) K. Yuan, H. Doucet, ChemCatChem 2013, 5, 3495; o) B. Li, P. H. Dixneuf, Chem. Soc. Rev. 2013, 42, 5744; p) R. Rossi, F. Bellina, M. Lessi, C. Manzini, Adv. Synth. Catal. 2014, DOI: 10.1002/adsc.201300922.

[3] a) J. J. Li, G. W. Gribble, Palladium in Heterocyclic Chemistry, Pergamon: Amsterdam, 2000; b) E. Negishi, Ed. Handbook of Organopalladium Chemistry for Organic Synthesis; Wiley-Interscience: New York, 2002; Part III, p 213.

[4] For examples of direct arylations of thiophenes: a) E. David, S. Pellet-Rostaing, M. Lemaire, Tetrahedron 2007, 63, 8999; b) H. A. Chiong, O. Daugulis, Org. Lett. 2007, 9, 1449; c) P. Amaladass, J. A. Clement, A. K. Mohanakrishnan, Tetrahedron 2007, 63, 10363; d) M. Nakano, H. Tsurugi, T. Satoh, M. Miura, Org. Lett. 2008, 10, 1851; e) B. Liégault, I. Petrov, S. I. Gorlesky, K. Fagnou, J. Org. Chem. 2010, 75, 1047; f) L. Chen, J. Roger, C. Bruneau, P. H. Dixneuf, H. Doucet, Chem. Commun. 2011, 47, 1872; g) K. Yuan, H. Doucet, Chem. Sci., 2014, 5, 392.

[5] For examples of direct arylations of furans: a) M. Parisien, D. Valette, K. Fagnou, J. Org. Chem. 2005, 70, 7578; b) E. M. Beccalli, G. Broggini, M. Martinelli, S. Sottocornola, Synthesis 2008, 136; c) B. Liégaut, D. Lapointe, L. Caron, A. Vlassova, K. Fagnou, J. Org. Chem. 2009, 74, 1826; d) M. Ionita, J. Roger, H. Doucet, ChemSusChem 2010, 3, 367.

[6] For examples of direct arylations of pyrroles or indoles: a) F. Bellina, S. Cauteruccio, R. Rossi, Eur. J. Org. Chem. 2006, 1379; b) X. Wang, D. V. Gribkov, D. Sames, J. Org. Chem. 2007, 72, 1476; c) N. Lebrasseur, I. Larrosa, J. Am. Chem. Soc. 2008, 130, 2926; d) P. Ehlers, A. Petrosyan, J. Baumgard, S. Jopp, N. Stein- 
[7] a) P. T. Anastas, J. C. Warner, Green Chemistry: Theory and Practice, Oxford University Press, New York 1998, p 30; b) T. Welton, Chem. Rev. 1999, 99, 2071; c) P. T. Anastas, M. M. Kirchhoff, Acc. Chem. Res. 2002, 35, 686.

[8] C. Fischmeister, H. Doucet, Green Chem. 2011, 13, 741.

[9] a) G. L. Turner, J. A. Morris, M. F. Greaney, Angew. Chem., Int. Ed. 2007, 46, 7996; b) S. A. Ohnmacht, P. Mamone, A. J. Culshaw, M. F. Greaney, Chem. Commun. 2008, 1241; c) E. Ferrer Flegeau, M. E. Popkin, M. F. Greaney, Org. Lett. 2008, 10, 2717; d) S. A. Ohnmacht, A. J. Culshaw, M. F. Greaney, Org. Lett. 2010, 12, 224; e) L. Joucla, N. Batail, L. Djakovitch, Adv. Synth. Catal. 2010, 352, 2929; f) Y.-X. Su, Y.-H. Deng, T.-T. Ma, Y.-Y. Li, L.-P. Sun, Green Chem. 2012, 14, 1979; g) G. Park, S. Lee, S. J. Son, S. Shin, Green Chem. 2013, 15, 3468.

[10] a) O. René, K. Fagnou, Org. Lett. 2010, 12, 2116; b) L. Ackermann, R. Vicente, Org. Lett. 2009, 11, 4922.

[11] a) J. Roger, C. Verrier, R. Le Goff, C. Hoarau, H. Doucet, ChemSusChem 2009, 2, 951; b) J. J. Dong, J. Roger, C. Verrier, T. Martin, R. Le Goff, C. Hoarau, H. Doucet, Green Chem. 2010, 12, 2053; c) S. Bensaid, N. Laidaoui, D. El Abed, S. Kacimi, H. Doucet, Tetrahedron Lett. 2011, 52, 1383; d) K. Beydoun, H. Doucet, ChemSusChem 2011, 4, 526; e) S. Bensaid, H. Doucet, ChemSusChem 2012, 5, 1559.

[12] a) P. Arockiam, V. Poirier, C. Fischmeister, C. Bruneau, P. H. Dixneuf, Green Chem. 2009, 11, 1871; b) P. Arockiam, C. Fischmeister, C. Bruneau, P. H. Dixneuf, Angew. Chem. Int. Ed. 2010, 49, 6629; c) L. A. Adrio, J. Gimeno, C. Vicent, Chem. Comm. 2013, 49, 8320.

[13] K. Tanaka, Solvent-free organic synthesis, WILEY-VCH Verlag GmbH \& Co., Weinheim 2003.

[14] R. B. Bedford, C. J. Mitchell, R. L. Webster, Chem. Commun. 2010, 46, 3095.

[15] R. K. Henderson, C. Jiménez-González, D. J. C. Constable, S. R. Alston, G. G. A. Inglis, G. Fisher, J. Sherwood, S. P. Binks, A. D. Curzons Green Chem. 2011, 13, 854.

[16] K. Watanabe, N. Yamagiwa, Y. Torisawa, Org. Proc. Res. Dev. 2007, 11, 251.

[17] a) P. Tundo, M. Selva, Acc. Chem. Res. 2002, 35, 706; b) T. Sakakura, K. Kohno, Chem. Commun. 2009, 1312; c) B. Schäffner, F. Schäffner, S. P. Verevkin, A. Börner, Chem. Rev. 2010, 110, 4554; d) P. T. Anastas, W. Leitner, P. G. Jessop, C. J. Li, P. Wasserscheid, A. Stark, Handbook of Green Chemistry - Green Solvents, Wiley_VCH 2010.

[18] H. Y. Fu, L. Chen, H. Doucet J. Org. Chem. 2012, 77, 4473.

[19] T. Cantat, E. Génin, C. Giroud, G. Meyer, A. Jutand, J. Organomet. Chem. 2003, 687, 365.

[20] a) F. Pozgan, J. Roger, H. Doucet ChemSusChem 2008, 1, 404; b) A. Battace, M. Lemhadri, T. Zair, H. Doucet, M. Santelli, Organometallics 2007, 26, 472; c) L. Zhao, C. bruneau, H. Doucet, ChemCatChem 2013, 5, 255.

I have no conflicts of interest 


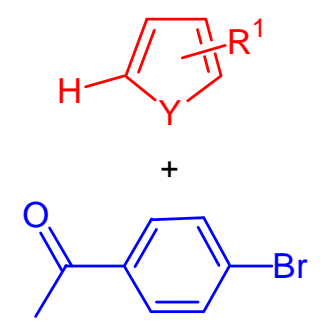

[Pd] 0.1-0.5 mol\%, KOAc

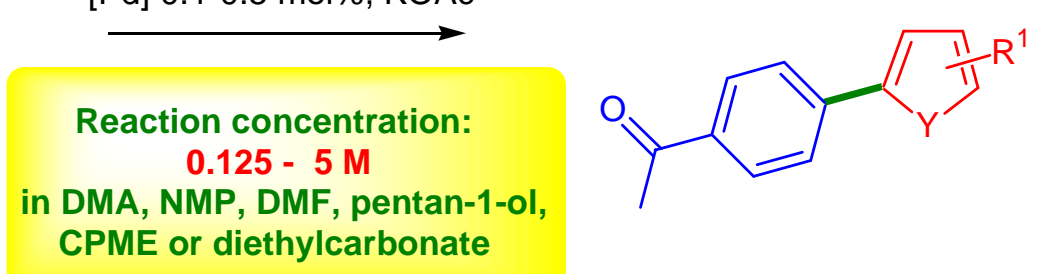

$\mathrm{Y}=\mathrm{S}, \mathrm{O}$ or $\mathrm{NMe}$ 